Sylwia Karolina Przewoźnik

ORCID: 0000-0002-0756-7996

Akademia Ignatianum w Krakowie

\title{
Uniwersalne i aktualne dylematy i paradoksy w życiu nauczyciela twórczego
}

\section{Universal and Present-day Dilemmas and Paradoxes in the Life of Creative Teacher}

\begin{abstract}
ABSTRAKT
Artykuł ma na celu ukazanie tradycyjnych i współczesnych dylematów i paradoksów obecnych w zawodzie nauczyciela oraz zwrócenie uwagi na znaczenie rozwoju twórczego potencjału uczniów. Rola zawodowa i status nauczycieli ulega ciagłym przeobrażeniom, m.in. na skutek zmieniających się nieustannie realiów życia. Nauczyciel powinien nie tylko przekazywać gotowq wiedzę, lecz uczyć jej zdobywania, wskazywać różne strategie uczenia się, rozwiq̨zywania problemów, kierować wszechstronnym rozwojem uczniów, zwracać szczególnq uwagę na rozwój osobowości i społecznych wartości wychowanków. Obecnie potrzebujemy zwłaszcza skutecznych działań edukacyino-wychowawczych, majacych na celu kształtowanie człowieczeństwa uczniów. Chodzi o ideę wyrażonq w greckiej paidei, a następnie w Powszechnej Deklaracji Praw Człowieka z 1948 r., polegajacq na tym, że w nauczaniu i wychowaniu chodzi o wszechstronny rozwój człowieka, możliwie pełne urzeczywistnianie jego potencjału osobowego, wyposażanie go w niezbędnq całościowq wiedzę o świecie i o nim samym. Chodzi zatem zarówno o kształtowanie kultury osobistej ucznia i wychowanka, jak i o skuteczne wprowadzenie
\end{abstract}

SLOWA KLUCZOWE nauczyciel, twórczość, szkoła, edukacja, kształcenie, globalizacja, dylematy, paradoksy

KEYWORDS

teacher, creativity, school, education, education, globalization, dilemmas, antinomies

SPI Vol. 23, 2020/4 ISSN 2450-5358 e-ISSN 2450-5366 DOI: 10.12775/SPI.2020.4.002

Nadesłano: 30.06 .2020 Zaakceptowano: 09.10.2020

Artykuły i rozprawy 
go w historycznie ukształtowanq kulturę oraz w świat uniwersalnych wartości, w tym wartości humanistycznych. I wreszcie - o udane przysposobienie go do życia indywidualnego i społecznego. Innymi słowy w tej idei chodzi ○ ukształtowanie człowieka ○ bogatej duchowości i rozbudowanej kreatywności, samodzielnej i krytycznej umysłowości oraz rozbudzonej wrażliwości moralnej i humanistycznej. Obecnie potrzeba nowoczesnej myśli pedagogicznej na miarę wielkich konstrukcji teoretycznych czołowych twórców „nowej pedagogii” ubiegłego stulecia, takich jak myśl pedagogiczna Johna Deweya, Stefana Szumana, Zygmunta Mysłakowskiego czy koncepcji edukacji permanentnej Bogdana Suchodolskiego.

\section{ABSTRACT}

The article aims to show traditional and contemporary dilemmas and paradoxes present in the teaching profession as well as to pay attention to the importance of developing the creative potential of pupils. The professional role and status of teachers is constantly changing due to permanently changing realities of life. The teacher should not only convey a set of knowledge but teach how to acquire it, indicating the various learning strategies, solving problems, guiding the comprehensive development of students, paying particular attention to the development of personality and social abilities of pupils. At present, we witness an unprecedent need of the effective educational activities aimed at shaping the humanity of students. It is about the idea expressed in the Greek paideia and then in the Universal Declaration of Human Rights of 1948, the idea, generally speaking, that teaching and upbringing are about the comprehensive development of man, about the full realization of his personal potential, about equipping him with the necessary comprehensive knowledge about the world and himself. It is therefore about shaping the personal culture of the pupil, as well as about effectively introducing him into a historically shaped culture and the world of universal values, including humanistic ones. And finally - it is about the successful adaptation to individual and social life. In other words, this idea is about shaping a person with a rich spirituality and developed creativity, an independent and critical mind, and an awakened moral and humanistic sensitivity. Currently, there is a need for modern pedagogical thought tailored to the great theoretical constructions of the leading authors of the "new pedagogy" of the last century, such as pedagogical thought developed by John Dewey, Stefan Szuman, Zygmunt Mysłakowski, or the concept of permanent education introduced by Bogdan Suchodolski. 


\section{Wstęp}

W dobie wszechobecnego postępu naukowego i technicznego człowiek zmuszony jest do nieustannego adaptowania się do otaczającej go rzeczywistości, stąd też niezwykle istotne w dzisiejszych czasach stały się umiejętności kreatywnego i twórczego myślenia oraz działania. Edukacja jest procesem wielowymiarowym, którego celem jest nie tylko przekazanie wiedzy, ale również kształtowanie umiejętności, norm i wartości. Warunkiem efektywnej edukacji jest uwzględnianie różnic między uczniami oraz dostosowanie nauczania do możliwości jednostki, by jak najpełniej owe potencjalności wykorzystać i rozwijać. Podstawowym zadaniem nauczyciela, bez względu na czasy, w których żyje, jest zapewnienie wszystkim uczniom optymalnego ze względu na ich potencjalne możliwości rozwoju intelektualnego. Nauczyciel powinien nie tylko zrealizować dany program edukacyjny przewidziany przez system oświaty, ale także dać uczniom ogólne narzędzia, dzięki którym będą mogli rozwijać zdolności krytycznego myślenia, uwagi, wyobraźni, fantazji oraz własnych zainteresowań. Wyzwanie, jakie przynoszą współczesne czasy, polega na jeszcze większej odpowiedzialności, jaka spoczywa na wychowawcy. Relatywizm moralny, prężnie rozwijająca się technologia, szybko zmieniająca się kultura - to wszystko stawia przed edukatorami olbrzymie wymagania.

W nowym myśleniu o edukacji i pedagogice daje się zauważyć dwa komplementarne kierunki badawcze. Jednym $z$ nich jest orientacja w stronę kompleksowości, ku przechodzeniu od wiedzy monocentrycznej do wielostronnej, otwieranie się na nowości oraz różnorodność i wieloaspektowość zjawisk. Edukacja ma przygotowywać młodych ludzi do życia w społeczeństwie, w świecie - takim, jaki jest i jaki będzie w kolejnych dziesięcioleciach, kiedy to dzisiejsi uczniowie osiągną etap dorosłości. To, czego i jak uczymy dzieci w szkole, musi zatem odpowiadać temu, czego potrzebują, by w takim właśnie świecie się odnaleźć, by się realizować, odnajdywać swoje miejsce w społeczeństwie. Edukacja musi się zatem zmieniać adekwatnie do zmian, jakie zachodzą w świecie i w społeczeństwie.

Trud roli nauczyciela w czasach transformacji dostrzega m.in. Anna Brzezińska. Autorka wskazuje na sprzeczne wymagania i tendencje formułowane pod adresem nauczycieli. $Z$ jednej strony od 
nauczyciela wymaga się, aby był strażnikiem tradycji, reprezentantem wiedzy „klasycznej”, instruktorem czynności powszechnie uznawanych za niezbędne i uniwersalne dla funkcjonowania człowieka w rzeczywistości społecznej, z drugiej zaś - chcemy wierzyć, a wręcz żądamy od nauczycieli, że przygotują uczniów do uczestnictwa $\mathrm{w}$ zmiennym i nieprzewidywalnym świecie, z potrzebnymi do tego kompetencjami (Brzezińska 2008: 35).

Współczesną edukację cechuje wielość paradoksów i rozbieżnych podejść teoretycznych. Najbardziej charakterystycznym, właściwie bezprecedensowym paradoksem jest to, że prawidłowy rozwój edukacji wymaga nowoczesnych metod i środków działania, a właściwie nowego paradygmatu myślowego. $\mathrm{Z}$ drugiej zaś strony ujawnia się w niej imperatywna potrzeba śmiałego, szerokiego i krytycznego zwrotu w kierunku tradycyjnego i klasycznego, uniwersalnego i historycznie wypróbowanego dorobku teoretycznego i metodycznego dawniejszych sztuk edukacyjnych (Szmyd 2019). Paradoksalność zawodu nauczycielskiego wyraża się już w tym samym, że jest to zawód w znacznej mierze taki, jak inne, ale jednak zasadniczo odmienny. Oprócz typowych cech takich jak: profesjonalizm, odpowiednie umiejętności i sprawności, dobrego fachowego przygotowania i stałego doskonalenia, niezbywalną i rozstrzygającą w nim rolę odgrywa czynnik podmiotowy: czynnik ludzki.

\section{Dysonanse edukacyine ponowoczesności}

Każdy, kto uważnie i krytycznie obserwuje współczesną rzeczywistość, uświadamia sobie, że cywilizacja, w której żyjemy, weszła w nową fazę swoich dziejów. Nie chodzi tu jedynie o gwałtowne przemiany we wszystkich niemal dziedzinach ludzkiego życia, ale o fundamentalne przewartościowania, jakie dokonują się na naszych oczach. W konsekwencji coraz więcej ekspertów z różnych dyscyplin wiedzy zgadza się $\mathrm{z}$ twierdzeniem, że w drugiej połowie XX wieku zakończyła się epoka modernizmu i nowoczesności, która w dziedzinie myślenia charakteryzowała się dążeniem do precyzyjnego, racjonalnego, naukowego poznania obiektywnej rzeczywistości, a w dziedzinie działania kierowała się dążeniem do osiągnięcia wysokiej skuteczności i efektywności we wszystkich podejmowanych przedsięwzięciach (Skolimowski 2009). Współczesny człowiek żyje 
w czasach głębokich zmian kulturowych, wynikających z rozwoju nowych technologii, przemian struktury społecznej, procesów globalizacji oraz dominacji mass mediów w kształtowaniu postaw i świadomości społecznej; żyje w świecie cywilizacji hałasu i chaosu medialnego, informacyjnego (Bauman 2000). O ile za atrybut minionych czasów, tzn. nowoczesności, uznawano działanie zgodne z pewnymi regułami, które wprowadzały porządek oraz umożliwiały przewidywanie mających nastąpić wydarzeń, o tyle współczesność całkowicie zrywa z tą zasadą, ukierunkowuje ona bowiem człowieka na podążanie za teraźniejszością, nastawioną na niełatwą do przewidzenia przyszłość i nie przygotowuje go do niej (Dziamski 1995). Zachodzące zmiany kulturowe i cywilizacyjne stanowią podłoże do dyskusji edukacyjnych, sama zaś pedagogika czasów postmodernizmu szuka dla siebie szans i korzyści w zachodzącym przesileniu kulturowym. W epoce społeczeństwa technokratycznego ma miejsce zasadnicza zmiana modeli życia i wzorców osobowych. Utrudnia to bądź wręcz uniemożliwia podtrzymywanie tradycyjnych wartości wychowawczych i edukacyjnych. Ponowoczesność jako nowy etap przemian i tendencji cywilizacyjnych nieuchronnie pociąga za sobą zasadnicze zmiany w sposobie myślenia o szkole i edukacji (Śliwerski 2003).

Wielu postępowych działaczy społecznych i myślicieli już dawno przypisywało wysoką rangę zawodowi nauczycielskiemu. Andrzej Frycz Modrzewski w dziele O poprawie Rzeczypospolitej stawiał „stan szkolny" na równi z najwyższymi stanami, zakładając, że tylko doskonały nauczyciel może zaszczepić uczniom prawdziwe cnoty. Twórca polskiej pedeutologii Jan Władysław Dawid w rozprawie O duszy nauczycielstwa pisał, że istotą nauczycielskiego powołania jest miłość dusz ludzkich, która stanowi podstawę efektywności pracy i procesów samokształcenia obok obowiązkowości, poczucia odpowiedzialności, sprawiedliwości i odwagi moralnej. Szkoła to instytucja oświatowo-wychowawcza, której zadaniem jest kształcenie i wychowanie. Pojawia się jednak szereg istotnych pytań: Czy rzeczywiście szkoła w pełni realizuje te zadania? Czy do współczesnej szkoły można mieć dziś zaufanie? Czy rzetelnie wypełnia swoje podstawowe zadanie przygotowania uczniów do życia w przyszłości? Ilu z nich może powiedzieć, że szkoła przygotowała ich do dorosłego życia? Czy absolwenci szkół potrafią sobie radzić $\mathrm{z}$ wyzwaniami, jakie przed każdym z nas stawia obecna rzeczywistość? 
Niewątpliwie prawdą jest, że szkoła kształci i wychowuje, ale realizując te zadania instytucja ta popełnia wiele błędów. Szkoła powinna kształcić umiejętności wykorzystania zdobytej wiedzy, co jest istotnym warunkiem funkcjonowania we współczesnym świecie. Nie można zmuszać ucznia do mechanicznego przyswajania określonej wiedzy w tzw. sposób encyklopedyczny. Należy zaś wkładać wiele wysiłku, aby wiedza ta przydała się w realiach współczesnego świata (Kwieciński 1995).

Bogusław Śliwerski przedstawił swoje refleksje związane $\mathrm{z}$ wykonywaniem zawodu nauczyciela. Wśród nich wymienił kilka tzw. "gorsetów" pedeutologicznych:

- gorset programowo-metodyczny, tzw. narodowe curriculum, czyli wymagania podstawy programowej kształcenia ogólnego,

- gorset ideologiczny, wynikający z konieczności „redukowania” własnego systemu wartości i przekonań, aby stać się „politycznie poprawnym",

- gorset temporalny, związany z czasem pracy nauczyciela, którego jest zwykle zbyt mało, aby rzetelnie i z pasją realizować swoje zadania,

- gorset jurydyzacji, dotyczący wprowadzonych (często modyfikowanych) norm prawnych, które „standaryzują” działania nauczyciela,

- gorset awansu zawodowego, który pojawił się wraz z reformą szkolnictwa w 1999 roku i jest związany z systemem nadawania stopni kwalifikacyjnych nauczyciela (Śliwerski 2015).

Przeobrażająca się ciągle rzeczywistość społeczna i oświatowa powoduje zmiany $\mathrm{w}$ treściach kształcenia, metodach pracy z uczniem, a także swoiście modyfikuje rolę nauczyciela. Narastająca fala krytyki kierowanej pod adresem współczesnych systemów szkolnych, w tym także nauczycieli, doprowadziła do zmian również we wzajemnych relacjach pedagoga i ucznia. Niewątpliwie należy się zgodzić z Janem Szmydem, który uważa, że jedną z poważniejszych i najbardziej niepokojących z punktu widzenia dostrzegalnych i przewidywalnych skutków sytuacji kryzysowych globalizującego się świata jest sytuacja we współczesnej edukacji, powszechnie uznawana za kryzys edukacyjny (Szmyd 2015).

W tej sytuacji jedynym remedium wydaje się być klasyczna paideia, która kładzie nacisk na wszechstronny intelektualny i moralny rozwój 
człowieka. Dlatego też współczesna teoria i praktyka pedagogiczna winny nie tylko wyczerpująco i dogłębnie odzwierciedlać własną epokę - jej cechy i właściwości, a zwłaszcza dokonujące się w niej głębokie przemiany, ale także skutecznie i w pożądany sposób oddziaływać na nią (Szmyd 2019).

\section{Nauczyciel w warunkach zmiany społecznej i edukacyjnej}

Edukacja, także edukacja akademicka - odwołując się do etymologii (słowo to wywodzi się od łacińskiego educare - wychowywać, kształcić; Milerski, Śliwerski 2000: 54) - jest procesem, w trakcie którego dochodzi (czy raczej powinno dochodzić) do „wyprowadzenia” edukowanego ze stanu niewiedzy, poznawczej, psychicznej i duchowej hibernacji oraz do zachęcenia go do odkrywania, doświadczania, rozumienia różnorodności świata oraz samego siebie (Adamska-Staroń 2009). Zatem edukować, to otworzyć przed edukowanym/uczniem swoistą przestrzeń, rozwinąć przed nim horyzont, na którym pojawią się idee, wiedza, wartości, zjawiska, zdarzenia, działania; to świadomie budować nastrój, rozbudzać wrażliwość na wspomniane jakości, na drugiego człowieka, na rozumienie, interpretowanie, doświadczanie, przeżywanie, samokształtowanie. Edukować, to zachęcać do nieustannego poszukiwania nowych kształtów istnienia, czyli wdrażać do twórczości, otwierać przed uczniem/studentem przestrzeń, w której będzie on miał szanse odnaleźć sens własnej egzystencji, własnego bycia w świecie.

Jak już zostało podkreślone, we współczesnej rzeczywistości dokonuje się wiele zmian technologicznych i społecznych w różnych obszarach życia. Coraz powszechniejsze staje się zainteresowanie jakością kształcenia i doskonaleniem umiejętności praktycznych oraz dostosowaniem wiedzy do nowoczesnych wymagań społecznych. Wszystko to powoduje konieczność samodoskonalenia zawodowego i podnoszenia kwalifikacji nauczycieli. W dzisiejszych czasach na nauczyciela patrzy się nie tylko przez pryzmat instytucji szkoły, ale także w kontekście roli, jaką ma do odegrania we współczesnym społeczeństwie i kulturze (Zieliński 2012: 57-71).

Szkoła doświadcza różnych problemów i trudności, jakie niesie współczesny świat. Jacy nauczyciele są zatem potrzebni we współczesnej oświacie? Próby odpowiedzi na to pytanie podjęli się m.in. 
Donald Schön, Henry Giroux, Joe Kincheloe, wyróżniając obok tradycyjnego nauczyciela następujące modele: „refleksyjny praktyk”, „transformatywny intelektualista” i „postpozytywistyczny praktyk” (Kupisiewicz 1994).

Koncepcję „refleksyjnego praktyka” wypracował Donald Schön, który wszedł z założenia, że w warunkach zmiennej rzeczywistości wiedza naukowa nie jest bezpośrednio przydatna, gdyż jest zbyt ogólna. Nauczyciel według niego powinien być praktykiem, który analizuje sytuacje praktyczne, jest „badaczem własnej praktyki” i poszukuje rozwiązań adekwatnych do konkretnych zadań. W ten sposób tworzy własne, niezależne od teorii naukowych teorie doraźne. Jego działaniu towarzyszy refleksja w postaci namysłu prowadzącego do przetwarzania danej sytuacji i jej przeanalizowania (Kupisiewicz 1980).

Twórcą koncepcji „transformatywnego intelektualisty” jest Henry Giroux. Według niego szkoła nie powinna być miejscem „urabiania” dzieci w celu przystosowania ich do warunków społecznych, kulturowych i politycznych. W sytuacji, gdy szkoła ma za zadanie włączać się w procesy tworzenia lepszego społeczeństwa, nauczyciel musi być otwarty na potrzeby środowiska, wykazywać chęć i umiejętność dyskutowania i obrony swoich racji. Nauczyciel powinien być „rzecznikiem postępu i demokracji” (Kupisiewicz 1980).

Mianem „transformatywnego intelektu” Giroux określa swoiste walory nauczyciela, które pozwalają mu być wiarygodnym i skutecznym w swych działaniach. Nauczyciel winien być zaangażowany w procesy demokratycznych przeobrażeń, umieć odczytywać zjawiska społeczne oraz skutecznie planować swoją pracę (Kupisiewicz 1999a).

Model „postpozytywistycznego praktyka” stworzył Joe Kincheloe. Przedstawił on wizerunek nauczyciela, który - jego zdaniem - odpowiada wyzwaniom obecnych i nadchodzących czasów. $\mathrm{Na}$ postawę takiego nauczyciela składa się dziesięć niezbędnych elementów:

- refleksyjność, polegająca na umiejętności analizowania własnej praktyki;

- wiązanie myślenia z kontekstem społecznym;

- aktywny udział w tworzeniu przez uczniów własnego obrazu świata;

- umiejętność improwizacji (myślenie w działaniu); 
- kształtowanie tolerancji dopuszczającej możliwość różnicy poglądów i postaw;

- umiejętność krytycznej autorefleksji osobistej i społecznej (dopuszczającej dialog z innymi);

- zaangażowanie w tworzenie demokracji szkolnej;

- znajomość różnic kulturowych w środowisku, respektowanie praw mniejszości i różnic kulturowych;

- nastawienie na działanie (związane z poznawaniem);

- wyczulenie na emocjonalną stronę kontaktu z uczniami (Kupisiewicz 1999b).

Również Czesław Banach zwraca uwagę na szczególną rolę nauczyciela w odnowie szkolnictwa i reformie edukacji. Wskazuje on pięć obszarów/celów edukacji oraz powinności nauczycielskich:

- pedagogiczne: poznawanie i przyswajanie wartości, umiejętności, zdobywanie wiedzy, uczenie się;

- społeczne: sterowanie i wspieranie ludzi w wyborze ich drogi edukacyjnej i aspiracji życiowych;

- polityczne: przygotowanie do aktywności społeczno-politycznej oraz do wartościowego życia w społeczeństwie obywatelskim i pluralistycznym, uczenie dialogu i negocjacji;

- kulturowe: zaszczepienie umiejętności i potrzeby uczestniczenia w kulturze oraz jej współtworzenia, aby uodpornić się na relatywizm, konsumpcjonizm i dominację „mieć nad być”;

- ekonomiczne: przygotowanie do pracy i zawodu, kształtowanie motywacji i kompetencji (Banach 2005: 40-52).

Rola nauczyciela w społeczeństwie technokratycznym jest niejednoznaczna. Niejednoznaczność ta wynika z różnicy podejść do jednostki, jej celów i zadań życiowych. Banach zwraca uwagę na nauczyciela-człowieka, gdyż - jak zauważa - dobry nauczyciel jest po pierwsze i przede wszystkim człowiekiem. Ten właśnie fakt jest najważniejszy i decydujący w wypełnianiu zawodu nauczyciela. Od tego, jakim jest człowiekiem, jakie posiada cechy osobowościowe oraz w jakim stopniu potrafi realizować swoje zadania w zmiennych warunkach współczesnej rzeczywistości społecznej i przyrodniczej, zależą w dużym stopniu zmiany we współczesnej szkole i edukacji, a także w kulturze i życiu społecznym. Dobry nauczyciel, kompetentny w realizacji celów i zadań wychowawczych, wykorzystuje w swojej pracy umiejętności prakseologiczne w zakresie diagnozowania 
i planowania pracy wychowawczej, jak też w doborze określonych metod, środków i realizacji postawionych zadań. To nauczyciel potrafiący oceniać siebie i innych oraz jakość procesów wychowawczych, jak też gotowy do zmian i twórczych rozwiązań, do doskonalenia swojej pracy i rozwijania współpracy ze szkołą i różnymi innymi podmiotami (Banach 2005: 40-52). Nauczyciel powinien być więc dobrym diagnostą, zarówno dzięki stałej obserwacji dziecka, jak również dzięki posiadanej empatii, umiejętności wczuwania się w świat jego uczuć i przeżyć, gdyż tylko wtedy będzie mógł zrozumieć świat dziecka, jego problemy oraz rozpoznać wiele jego potrzeb. Jednym z podstawowych zadań opiekuna-wychowawcy jest wspieranie (samo)rozwoju wychowanka (Korczak 1992).

Według Jana Władysława Dawida na istotę „duszy nauczycielstwa” składają się takie cechy jak: miłość dusz ludzkich, potrzeba doskonałości, poczucie odpowiedzialności i obowiązku, wewnętrzna prawdziwość i moralna odwaga. Zygmunt Mysłakowski w rozprawie Co to jest talent pedagogiczny stwierdza, że istotną cechą talentu pedagogicznego jest kontaktowość, a jej tło stanowią: żywość wyobraźni, instynkt rodzicielski, zdolność do wyrażania uczuć i nastawienie psychiki na zewnątrz. Natomiast według Stefana Szumana osobowość doskonałego nauczyciela tworzą dwa elementy: pierwszym jest to, co nauczyciel posiadł i ma do rozdania, drugim - sposób rozdawania, zwłaszcza umiejętność oddziaływania na innych. Bogata osobowość, dojrzały charakter, wielka wiedza i piękna dusza nie stanowią jeszcze talentu, podobnie jak umiejętność oddziaływania, zdolności agitacyjne lub kontaktowość. Dopiero harmonijne współwystępowanie wszystkich elementów warunkuje pełną osobowość nauczyciela (Okoń 1962: 15).

W dzisiejszych czasach widać potrzebę, wręcz konieczność wypracowania nowego modelu nauczyciela. $Z$ jednej strony nauczyciela, przed którym będą stawiane „stare”, uniwersalne zadania, a z drugiej zaś - który będzie musiał występować w nowych i wymagających rolach oraz podejmować nowe wyzwania. Mówiąc bardziej konkretnie: z obszaru głównych celów i zadań edukacyjnych, jakie stoją przed współczesnym nauczycielem, czyli edukacji „na teraz” i „na przyszłość", zarysowują się obok „starych” czy tradycyjnych funkcji także "nowe” i historycznie cele oraz zadania. Chodzi o to, że w minionych epokach kształcenie i wychowanie, obok elementarnej funkcji 
personalnej, tzw. działania na rzecz rozwoju umysłowego, emocjonalnego, osobowościowego i fizycznego, spełniało przede wszystkim funkcję przystosowawczą: kulturową i zawodową, tzn. przysposabiało do życia w społeczeństwie, kulturze i do wykonywania życiowo niezbędnych czynności (Szmyd 2019). Zadaniem współczesnych pedagogów jest zatem przystosowanie nowego pokolenia do zastanej rzeczywistości. Uczenie kreatywności, samokrytyki, pobudzanie do innowacji, twórczości, nabywania kompetencji do pracy na rzecz zmiany otaczającego świata. Konsekwencją tego jest inne ujmowanie celów kształcenia, połączone $\mathrm{z}$ orientacją na podmiotowość uczestników procesu edukacyjnego oraz na postrzeganie nauczania jako procesu twórczego itp. (Bereźnicki 2004). Niewątpliwie uczenie zachowawcze, czyli polegające na nabywaniu ustalonych metod i zasad postępowania sprawdzonych w poprzednich pokoleniach, dzisiaj już nie wystarcza. Potrzebny jest nowy typ uczenia się, dostosowany do istniejących problemów. Wprowadzenie nowego systemu nauczania jest niezwykle trudne, gdyż wiąże się z przeobrażeniem całego współczesnego szkolnictwa, co odnosi się również do nauczycieli (Bereźnicki 2004). Najbardziej znamiennym rysem czasów „permanentnej zmiany" jest wykształcenie u jednostki umiejętności przetwarzania, rekonstrukcji oraz wykorzystywania wiedzy, służącej aktywnemu radzeniu sobie z rzeczywistością. W tym sensie współczesna edukacja jest rozumiana jako „ogół wpływów na jednostki [...] sprzyjających takiemu ich rozwojowi i wykorzystaniu posiadanych możliwości, aby w maksymalnym stopniu [...] stały się zdolne do aktywnej samorealizacji, niepowtarzalnej i trwałej tożsamości i odrębności, były zdolne do rozwijania własnego JA w toku spełniania «zadań ponadosobistych», poprzez utrzymywanie ciągłości własnego JA w toku spełniania «zadań dalekich»" (Kwieciński 1995).

\section{Twórczość jako niezbędny element kompetencii nauczyciela}

W czasach współczesnych model edukacji oparty na transmisyjnym przekazie wiedzy oraz umiejętności jej bezrefleksyjnego reprodukowania odchodzi w przeszłość. Podstawowe zadanie szkoły polega na przygotowaniu ucznia do życia w zmieniającym się dynamicznie otoczeniu, świecie technologii informacyjnej, który emanuje różnorodnością wiadomości. Niewątpliwie praca w zawodzie 
nauczyciela była i dalej być powinna powołaniem. Od osoby decydującej się na pracę z młodymi ludźmi wymaga się dziś otwartości i wrażliwości na potrzeby wychowanków oraz umiejętności towarzyszenia im $\mathrm{w}$ rozwoju. To od nauczyciela i jego sposobu pracy $\mathrm{z}$ uczniami zależy, czy będzie on wspomagał, czy hamował motywację tak niezbędną do bycia twórczym. Czy zatem nauczyciel polskiej szkoły może kształtować kreatywne postawy dzieci i młodzieży?

Twórcza aktywność młodego człowieka, będąca działaniem niestereotypowym i prowadzącym do niecodziennych rozwiązań, winna się stać podstawą edukacji. Zasługuje ona na to, by być dostrzeżoną i docenioną przez nauczycieli. Przez aktywność taką rozumie się chętnie podejmowaną działalność, która przynosi zadowolenie, jest oparta na własnych pomysłach, świadoma celu, stymulowana przez zadania zintegrowane $\mathrm{z}$ potrzebami jednostki (Krzywoń 2008). Aktywność twórcza to wszelka aktywność poznawcza i emocjonalno-motywacyjna prowadząca do subiektywnie bądź obiektywnie nowych i wartościowych wytworów w różnorodnych dziedzinach życia (Dąbek 1998).

Przez postawę twórczą Bogdan Suchodolski rozumie pewną postawę wobec życia, mającą swój wyraz w umiejętności samodzielnego myślenia i rozwiązywania nieznanych problemów i zadan. Występuje ona tam, gdzie powstają nowe jakości i wartości będące wynikiem osobistych działań i poszukiwań (Suchodolski 1980).

Zdaniem Krzysztofa Szmidta, podstawą celów kształcenia i wychowania powinno się stać dążenie do kształtowania człowieka twórczego. Podaje on listę cech, które mogą się przyczynić do określenia takiego wzorca. Należą do nich: szczególny sposób postrzegania świata, otwartość umysłu, niezależność i odwaga, spontaniczność i ekspresyjność, brak obawy przed nieznanym, zdolność koncentracji i fascynacja zadaniem, życzliwość i poczucie humoru oraz zdolność do integrowania przeciwieństw. To tylko niektóre, ale zdaniem psychologów istotne właściwości osoby wykazującej się postawą twórczą. Do czynników mających wpływ na twórcze myślenie należą niewątpliwie: płynność, giętkość i oryginalność myślenia oraz wrażliwość na problemy (Szmidt 2007). Natomiast według Stanisława Popka postawa twórcza to aktywny stosunek do świata i życia, wyrażający się potrzebą poznania i świadomego przetwarzania zastanej rzeczywistości i własnego ja (Popek 1988). 
Usystematyzowaną ścieżką rozwijania kreatywności ucznia jest dydaktyka twórczości, która wyznacza kierunek poszukiwań w zakresie rozwijania twórczego potencjału ucznia. W publikacjach z zakresu dydaktyki twórczości odnaleźć można między innymi modele wspierania twórczości, zasady i metody twórczości, które mogą stanowić pierwszy wyznacznik wspierania działań twórczych ucznia (Szmidt 2007). Niewątpliwie młody człowiek jest zdolny do kształtowania własnej osobowości, dlatego wychowawca-nauczyciel winien mieć stale na uwadze autentyczne dobro i szczęście ucznia. W podejmowanych działaniach edukacyjno-wychowawczych winna mu zawsze towarzyszyć perspektywa prawidłowego ukształtowania go na człowieka wielostronnie rozwiniętego (Surma 2012).

Krzysztof Szmidt (2007) wyróżnia dwa modele rozwijania twórczego potencjału: (1) Model eliminowania barier - zakłada, że każdy człowiek posiada potencjał twórczy, który jest często blokowany przez bariery wewnętrzne i zewnętrzne. Zadaniem programów dydaktycznych jest likwidowanie barier blokujących twórczy potencjał człowieka. Metody oddziaływań powinny zatem polegać na zwalczaniu takich barier jak: sztywność myślenia, dominacja myślenia analitycznego, przesadne dążenie do sukcesu, konformizm, brak tolerancji dla różnorodności i sprzeczności. (2) Model stymulowania zdolności twórczych - wskazuje, że nie każdy człowiek wykazuje zdolności twórcze, dlatego podczas warsztatów i treningów trzeba zastosować określone procedury i techniki ich rozwijania. Ich głównym celem jest symulowanie płynności, giętkości i oryginalności myślenia (Szmidt 2007).

Rysunek 1. Modele rozwijania twórczego potencjału

Modele rozwijania twórczego potencjału

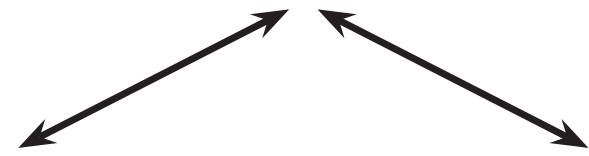

Model

eliminowania barier

Model

stymulowania zdolności twórczych

Źródło: opracowanie własne na podstawie: Szmidt (2007). 
Do rozwoju ludzkich uzdolnień potrzebne są odpowiednie warunki. Zdaniem Kazimierza Czarneckiego, przy względnie wysokiej inteligencji ogólnej i uzdolnieniach kierunkowych, potrzebna jest odpowiednia stymulacja, czyli system opieki nad twórczym rozwojem. Wymienia on następujące metody wspomagania rozwoju twórczych ludzi:

- metody stymulujące rozwój twórczy: rozmowa, dyskusja, wymiana myśli na tematy życia twórczego ludzi;

- metody aktywizujące rozwój twórczy: zachęta do działania twórczego, przekonywanie, wyzwalanie energii twórczej;

- metody wyzwalające twórcze myśli i działania: współdziałanie, wspólpraca, konkretna pomoc, współzawodnictwo;

- metody kształtujące kierunek i treści działania twórczego: działanie samodzielne, projektowanie, konstruowanie, tworzenie pomysłów i ich realizacja.

Dobór metody musi być dopasowany do etapów rozwoju i potencjalnych możliwości tworzenia, jak również kierunku i dziedziny twórczości jednostki (Czarnecki 1996).

Proces twórczy obejmuje następujące fazy:

a) odkrycie problemu,

b) analizowanie sytuacji problemowej,

c) wytwarzanie pomysłów rozwiązywania problemu,

d) weryfikowanie pomysłów rozwiązywania problemu (Kozielecki 1969).

Niewątpliwie w edukacji dzieci i młodzieży poszukiwać należy nowatorskich strategii edukacji, których celem będzie stymulowanie rozwoju ich potencjału twórczego. $Z$ badań Krzysztofa Szmidta (Szmidt 2018), dotyczących analizy różnorodnych programów nauczania twórczości, wynika, że w wychowaniu do twórczości chodzi o całą postawę twórczą (aspekt poznawczy, emocjonalny oraz behawioralny). Twórczość nie jest bowiem tylko fenomenem umysłowym i nie wystarczy pobudzanie jedynie procesów poznawczych (myślenia twórczego) (Szmidt 2018). Własna aktywność dziecka, począwszy od najwcześniejszych okresów życia, ma w znacznej mierze charakter twórczy i to nie tylko u dzieci wyjątkowych, szczególnie pod jakimś względem utalentowanych, lecz po prostu u większości całkiem dzieci, jeśli tylko rozwijają się w środowisku, które nie hamuje wyraźnie ich wrodzonej skłonności do aktywnego eksplorowania 
i przekształcania świata. Ważne jest inspirowanie do działania oraz systematyczne, a nie okazjonalne, motywowanie do podejmowania działań twórczych. Podkreśla się szczególną rolę nauczyciela jako osoby „pomagającej w rozwoju i tworzeniu” poprzez organizowanie takich sytuacji edukacyjnych, które będą wyzwalały aktywność własną dziecka, jego zaangażowanie w rozwiązywanie zadań o charakterze otwartym i półotwartym, uruchamianie zasobów wewnętrznych i zewnętrznych w obszarach mowy i myślenia (Płóciennik 2011).

Podsumowując rozważania niektórych pedagogów i psychologów na temat twórczości i postawy twórczej, należy podkreślić, że wspólne jest stwierdzenie, iż postawa twórcza to aktywny stosunek do świata, chęć poznania, to wyrażanie siebie, pewna dyspozycja emocjonalno-motywacyjna, która w sprzyjających warunkach zewnętrznych pozwala tworzyć lub odkrywać. Zatem odpowiednie stymulowanie i kierowanie młodego człowieka może rozwinąć w nim cechy postawy twórczej. Szczególną rolę w ich rozwijaniu upatruje się w systemie edukacyjnym. Aktywność jest warunkiem rozwoju człowieka i prawidłowej regulacji jego stosunków z otoczeniem. $\mathrm{Cy}$ tując słowa Korczaka, „Wychowawca, który nie wtłacza, a wyzwala, nie ciągnie, a wznosi, nie ugniata, a kształtuje, nie dyktuje, a uczy, nie żąda, a zapytuje - przeżyje wraz z dzieckiem wiele natchnionych chwil, łzawym wzrokiem nieraz patrzeć będzie na walkę anioła z szatanem, gdzie biały anioł triumf” (Korczak 1993). Współczesna pedagogika szczególną rolę w procesie uczenia się i rozwoju przypisuje aktywności własnej wychowanka. Jej organizowanie i stymulowanie stanowi zatem najważniejsze zadanie edukacyjne szkoły. W pedagogice szkolnej czynnikiem integrującym treści, strategie, metody i formy kształcenia oraz kontrolę i ocenę osiągnięć ucznia jest nauczyciel. Może on i powinien podejmować działania sprzyjające aktywizacji poznawczej oraz twórczej uczniów. Organizując tego rodzaju działalność, nauczyciel musi być zorientowany w źródłach zainteresowań uczniów. Najbardziej efektywnym sposobem rozwijania twórczej aktywności uczniów jest stosowanie strategii nauczania problemowego, w którym dominują metody samodzielnego dochodzenia do wiedzy. 


\section{Zakończenie}

Z powyższych rozważań wynika konieczność kształtowania nowego typu myślenia i podejścia do kształcenia, tworzenia innowacyjnej filozofii i jej realizacji w praktyce oraz szersze spojrzenie na instytucje edukacyjne, które w zmiennym otoczeniu muszą antycypować zmiany i dostosowywać do nich swoje działania edukacyjne. Nauczyciele zawsze pełnili swoją rolę w określonych warunkach społecznych. Niejednokrotnie doświadczali problemów związanych z różnymi aspektami funkcjonowania szkoły. Przedstawienie problemów, jakich mogą doświadczyć nauczyciele we współczesnej szkole, umożliwia zrozumienie specyfiki pracy nauczyciela, przeżywanych przez niego dylematów i specyfiki roli, jaką pełni w społeczeństwie. Nauczyciele od wieków borykali się z wieloma problemami, które do dziś pozostają aktualne. Należą do nich przede wszystkim:

1. problemy dotyczące funkcjonowania członków społeczności szkolnej: uczniów i nauczycieli;

2. problemy dydaktyczne związane $z$ procesem nauczania;

3. problemy finansowo-organizacyjne;

4. technokratyzacja społeczeństwa;

5. wypalenie zawodowe.

Niewątpliwie tzw. pedagogie postmodernizmu stanowią odrębną jakość w myśli edukacyjnej w porównaniu z dorobkiem teoretycznym i ideowym „dawnych sztuk edukacyjnych”. Opierają się one na odrębnych paradygmatach myślowych i zawierają wiele treści światopoglądowych, etycznych, humanistycznych i pedagogicznych. Te ogólne analogie „nowej edukacji” pedagogiki tzw. społeczeństwa technokratycznego/rynkowego przejawiają się w wielu skonkretyzowanych tendencjach i działaniach. Edukacja nie może być tylko „produkcją wiedzy”, służyć powinna kształceniu obywateli, którzy będą zdolni do sprawowania kontroli nad własnym życiem, nad warunkami tworzenia i zdobywania wiedzy. W związku z powyższym przed nauczycielem/wychowawcą stoi nader trudne zadanie: przysposobienie wychowanków do aktywnego życia w społeczeństwie opartym na zasadach demokracji, wolności i sprawiedliwości, współdziałania i twórczej aktywności. Dobry nauczyciel według większości pedeutologów normatywnych oraz samych nauczycieli to nie tylko ten, kto wyposażony jest w niezbędną w działaniu wiedzę i technologię 
nauczania, odpowiedni zasób umiejętności i sprawności dydaktycznych, ale także - i być może przede wszystkim - ten, kto posiada bogatą osobowość i kulturę osobistą, kto legitymuje się szeroką skalą uznanych w pedeutologii normatywnej za niezbędne u dobrego nauczyciela cech i zalet osobowych. Bez względu na to, jak swoista i bogata jest ta osobowość i ile pozytywnych cech da się jej przypisać, zawsze jest ona pożądana i oczekiwana w omawianym tu zawodzie, bez niej nie sposób być dobrym nauczycielem. Wynika to z podwójnej, ale niestety nie zawsze możliwej do harmonijnego wypełniania przez nauczyciela funkcji owego zawodu, tzn. funkcji dydaktycznej i wychowawczej. Obecnie szkoła potrzebuje nauczyciela-przewodnika, opiekuna oraz organizatora życia i działania zbiorowego uczniów. Musi to być człowiek umiejący współpracować ze swoimi wychowankami w atmosferze wzajemnej życzliwości. Według Szumana w zawodzie pedagogicznym osobowość odgrywa kluczową rolę, „bo przecież nauczyciel nie jest bezdusznym zbiornikiem wiedzy, nie jest mówionym podręcznikiem, nie jest naczyniem, w którym wiedza zostaje mechanicznie zdeponowana i nagromadzona, aby stąd niejako rozlewano ją do - na razie - jeszcze mniej pojemnych naczyń, którymi są umysły uczniów" (Szuman 1962: 90).

Zawód nauczyciela z punktu widzenia potrzeb szkolnictwa wymaga więc „[...] nie tyle specjalnych, wybitnych uzdolnień i talentów, ile ludzi gotowych do oddania się swemu zawodowi. Nastawienie to powinno być tak silne $\mathrm{i}$ istotne, aby $\mathrm{z}$ indywidualnych i neutralnych związków i dyspozycji wyrosły uzdolnienia i żeby osobowość, gotowa do podjęcia misji pedagogicznej wobec tego zadania, dążyła do pogłębienia, do bogactwa wewnętrznego i do dojrzałości duchowej” (Szuman 1962: 90).

\section{Bibliografia}

Adamska-Staroń M. (2009). Edukacyjna przestrzeń - Pedagogiczne idee - Ku czemu powwrót?, „Podstawy Edukacji”, t. 2: Ciągłość i zmiana, s. 89-103.

Banach C. (2005). Szanse i zagrożenia rozwoju edukacji w Polsce, „Kultura i Edukacja", nr 2, s. 40-52.

Bauman Z. (2000). Globalizacja. I co z tego dla ludzi wynika, przeł. E. Klekot, Warszawa: Państwowy Instytut Wydawniczy.

Bereźnicki F. (2004). Dydaktyka ksztatcenia ogólnego, Kraków: Oficyna Wydawnicza „Impuls”. 
Brzezińska A. (2008). Nauczyciel jako organizator spotecznego środowiska uczenia się, [w:] Rozwijanie zdolności uczenia się. Wybrane konteksty i problemy, red. E. Filipiak, Bydgoszcz: Wydawnictwo UKW, s. 35-50.

Czarnecki K. (1996). Rozwój twórczy cztowieka, [w:] Twórczy rozwój nauczyciela, red. S. Juszczyk, Kraków: Oficyna Wydawnicza „Impuls”, s. 74-85.

Dąbek A. (1998). Psychologiczne podstawy twórczej aktywności dziecka, Zielona Góra: Wydawnictwo Wyższej Szkoły Pedagogicznej.

Dziamski G. (1995). Ponowoczesna śrwiadomość estetyczna, [w:] Trudna ponowoczesnośc. Rozmowy z Zygmuntem Baumanem, cz. 1, red. A. Zeidler-Janiszewska, Poznań: Wydawnictwo Fundacja Humaniora.

Korczak J. (1993). Jak kochać dziecko. Dziecko w rodzinie, https://wolnelektury.pl/media/book/pdf/dziecko-w-rodzinie.pdf [dostęp : 12.06.2020].

Kozielecki J. (1969). Rozwiązywanie problemów, Warszawa: PZWS.

Krzywoń D. (2008). Kraina kreatywności. Sposoby przeciwdziatania rutynie w pracy z dziećmi poprzez ekspresję twórczq i artystycznq, Sosnowiec: Oficyna Wydawnicza „Humanitas”.

Kupisiewicz C. (1980). Przemiany edukacyjne w świecie, Warszawa: Wiedza Powszechna.

Kupisiewicz C. (1994). Koncepcje reform szkolnych w latach osiemdziesiatych, Warszawa: Wydawnictwo, Żak”.

Kupisiewicz C. (1999a). Zarys koncepcji przebudowy systemu szkolnego w Polsce, Warszawa: Państwowe Wydawnictwo Naukowe.

Kupisiewicz C. (1999b). Paradygmaty i wizje reform oświatowych, wyd. 4, Warszawa: Wydawnictwo Akademickie „Żak”.

Kwieciński Z. (1995). Socjopatologia edukacji, Olecko: Mazurska Wszechnica Nauczycielska.

Milerski B., Śliwerski B. (red.). (2000). Pedagogika. Leksykon PWN, Warszawa: Wydawnictwo Naukowe PWN.

Okoń W. (oprac.). (1962). Osobowość nauczyciela. Rozprawy J. Wt. Dawida, Z. Mystakowskiego, St. Szumana, M. Kreutza, St. Baleya, Warszawa: Wydawnictwo PZWS.

Płóciennik E. (2011). Stymulowanie zdolności twórczych dziecka, Łódź: Wydawnictwo Uniwersytetu Eódzkiego.

Popek S. (1988). Aktywność twórcza dzieci i mtodzieży, Warszawa: WSiP.

Pyżalski J. Kołodziejczyk J. (2015). Nauczyciel wobec sytuacji trudnych wychowawczo, [w:] Wychowawcze i spoteczno-kulturowe kompetencje wspótczesnych nauczycieli. Wybrane konteksty, red. J. Pyżalski, Łódź: the Q studio, s. 77-94.

Skolimowski H. (2009). Prawda a problem ludzkiej egzystencji, [w:] Poznanie a prawda, red. A.L. Zachariasz, Rzeszów: Wydawnictwo Uniwersytetu Rzeszowskiego, s. 207-219.

Suchodolski B. (1980). Pedagogika. Podręcznik dla kandydatórw na nauczycieli, Warszawa: Państwowe Wydawnictwo Naukowe. 
Surma B. (2012). Teoretyczne zatożenia ksztattowania postawy twórczej dzieci w wieku przedszkolnym, „Edukacja Elementarna w Teorii i Praktyce”, nr 4(26), s. 13-27.

Szmidt K.J. (2003). Dydaktyka twórczości. Koncepcje, problemy, rozwiązania, Kraków: Oficyna Wydawnicza „Impuls”.

Szmidt K.J. (2007). Pedagogika twórczości, Gdańsk: Gdańskie Wydawnictwo Psychologiczne.

Szmidt K.J. (2018). Kreatywność - twórczość - postawa twórcza. Próba systematyzacji pojęć i teorii, [w:] Alternatywy w edukacji, red. B. Śliwerski, A. Rozmus, Kraków-Rzeszów: Oficyna Wydawnicza „Impuls”, Wyższa Szkoła Informatyki i Zarządzania, s. 97-127.

Szmyd J. (2015). Zagrożone człowieczeństwo. Regresja antropologiczna w świecie ponowoczesnym, Katowice: Wydawnictwo Naukowe „Śląsk”.

Szmyd J. (2019). Moc i niemoc edukacji $i$ wychowania w spoteczeństwie rynkowym. Wglad krytyczny i prospektywny. Katowice: Wydawnictwo Naukowe „Śląsk”.

Szuman S. (1962). Talent pedagogiczny, [w:] W. Okoń (red.), Osoborwość nauczyciela. Warszawa: PZWS, s. 90-134.

Śliwerski B. (2003). Nauki o wychowaniu wobec wyzwań postmodernizmu, „Chowanna”, R. 46(59), t. 1(20), s. 9-18.

Śliwerski B. (2015). Nauczyciele w gorsecie MEN-owskich regulacji, [w:] Ucztowieczyć komunikację. Nauczyciel wobec ucznia w przestrzeni szkolnej, red. H. Kwiatkowska, Kraków: Oficyna Wydawnicza „Impuls”, s. 57-83.

Zieliński P. ( 2012). Rola nauczyciela w świetle zatożen edukacji postmodernistycznej, „Pedagogika. Prace Naukowe Akademia im. Jana Długosza w Częstochowie", t. 21, s. 58-69.

\section{ADRES DO KORESPONDENCJI}

\section{Dr Sylwia Przewoźnik}

Akademia Ignatianum w Krakowie Instytut Psychologii

e-mail: sylwia.przewoznik_z@ignatianum.edu.pl 